\title{
PENGELOLAAN HUBUNGAN MASYARAKAT DAN KORELASINYA DENGAN MUTU PELAYANAN PENDIDIKAN MADRASAH ALIYAH SWASTA (MAS) DI KOTA BINJAI 2018
}

\author{
M. Dian Wahyudi, Ana \\ DOSEN STKIP BUDIDAYA BINJAI
}

\begin{abstract}
ABSTRAK
Penelitian ini bertujuan untuk mengetahui: (1) pengelolaan hubungan Masyarakat dan korelasinya dengan mutu pelayanan Pendidikan Madrasah Aliyah Swasta di Kota Binjai, (2) terdapat hubungan yang positif antara hubungan masyarakat dengan mutu pelayanan Pendidikan Madrasah Aliyah Swasta di Kota Binjai, (3) secara bersama-sama terdapat hubungan yang positif dan signifikan antara pengelolaan hubungan masyarakat dengan Mutu Pelayanan Pendidikan Madrasah Aliyah Swasta di Kota Binjai. Penelitian ini merupakan penelitian kuantitatif jenis korelasional. Populasi Penelitian ini adalah seluruh Guru-guru Madrasah Aliyah Swasta di kota Binjai yang berjumlah 53 Guru, mean 32,04, median 32,6, modus 33,9, SD 4,27, Secara umum dapat disimpulkan bahwa 32 guru atau 60,37 \% skor variabel X Pengelolaan Hubungan Masyarakat di atas nilai rata-rata dan 21 guru atau $39,63 \%$ berada dibawah nilai rata-rata. disamping itu diketahui bahwa frekuensi tertinggi pada kelas interval 32-34 dan terendah pada imterval 20-22 dan 23-25, sedangkan variabel Y Mutu Pelayanan Masyarakat Secara umum dapat disimpulkan bahwa 33 guru atau 62,26\% skor variabel Mutu Pelayanan Pendidikan Madrasah Aliyah Swasta diatas nilai rata-rata dan 20 guru atau $37,74 \%$ berada dibawah nilai rata-rata.disamping itu diketahui bahwa frekuensi tertinggi pada kelas interval 32-34 dan terendah pada interval 20-22, didapatkan $r_{x y}=0,952$ (tergolong tinggi), sedangkan $r_{\text {tabel }}=0,274$ pada taraf signifikan 5\%, instrumen yang digunakan dalam Penelitian ini adalah Angket, adapun Prosedur Penelitian ini menggunakan tiga tahap yaitu, tahap pertama perencanaan, kedua pelaksanaan penelitian dan ketiga tahap Evaluasi.
\end{abstract}

Kata Kunci : Hubungan Masyarakat dan Mutu Pelayanan Pendidikan Madrasah Aliyah (MAS) Swasta di Kota Binjai 


\section{A. Pendahuluan}

Lembaga pendidikan semakin dituntut memberikan manajemen dan layanan yang profesional kepada masyarakat. Hal ini dikarenakan semakin meningkatnya minat dan kebutuhan masyarakat melanjutkan pendidikan. Masyarakat sebagai salah satu konsumen lembaga pendidikan sekarang lebih kritis dan realitis dalam memilih lembaga pendidikan. Sikap masyarakat seperti itu menuntut lembaga pendidikan untuk tetap menjaga dan meningkatkan image yang positif lembaganya di mata masyarakat. Kondisi saat ini sangat menuntut sekolah tersebut menjadi lembaga pengemban amanat ilmu pengetahuan untuk menjawab keberadaannya secara ideal. Sekolah tersebut harus benar-benar bisa menempatkan diri dan melaksanakan manajemen secara baik agar selalu siap mengikuti perubahan.

Membangun sektor pendidikan tidak pernah akan mencapai tujuan akhir yang sempurna dan final. Hal ini terjadi karena konteks pendidikan selalu dinamis, berubah atau tidak pernah konstan, sesuai dengan perubahan masyarakat, ilmu pengetahuan dan teknologi. Terlebih-lebih pada era global sekarang ini karena arus informasi secara survival bebas keluar masuk di wilayah semua negara. Keterbukaan dalam berbagai sistem kehidupan secara terus menerus akan menjadi wacana dan cita-cita yang penting bagi kehidupan masyarakat.

Konsep yang terdapat pada manajemen peningkatan mutu sekolah seharusnya lebih memfokuskan diri pada perbaikan proses pendidikan secara terus-menerus dan berkesinambungan. Menurut Zahror (2014:33) beberapa karakter dari konsep manajemen mutu sekolah adalah: (1) lingkungan sekolah yang aman dan tertib; (2) sekolah memiliki misi dan target mutu yang ingin dicapai; (3) sekolah memiliki kepemimpinan yang kuat; (4) adanya harapan yang tinggi dari personel sekolah untuk berprestasi; (5) adanya pengembangan staf sekolah yang terus-menerus sesuatu tuntutan IPTEK; (6) adanya pelaksanaan evaluasi yang terus-menerus terhadap berbagai aspek akademik dan administrasi, dan pemanfaatan hasilnya untuk penyempurnaan/ perbaikan mutu; dan (7) adanya komunikasi dan dukungan intensif dari orang tua siswa/ masyarakat. Salah satu dari tujuh aspek yang dipaparkan di atas adalah dukungan orang tua dan masyarakat sebagai pelanggan sekolah.

Saroni (2006:51) menyatakan pada dasarnya sekolah dan masyarakat merupakan satu kesatuan yang tidak dapat dipisahkan. Sekolah ada karena dibutuhkan oleh masyarakat untuk mencerdaskan anak-anaknya dan sekolah didirikan untuk mengkontribusi kebutuhan masyarakat akan institusi yang menyelenggarakan proses pendidikan. Dengan kata lain, masyarakat membutuhkan sekolah yang dapat memberikan pengetahuan yang baik 
untuk anak-anak mereka. Hal ini sejalan dengan pendapat Mulyasa (2005:50) bahwa sekolah dan masyarakat memiliki hubungan yang sangat erat dalam mencapai tujuan sekolah atau pendidikan secara efektif dan efisien.

Sejalan dengan upaya reformasi pendidikan nasional melalui program Manajemen Berbasis Sekolah (MBS) mengharuskan hubungan sekolah dengan keluarga dan masyarakat perlu direformasi sehingga tanggung jawab pendidikan bukan hanya dibebankan kepada sekolah. Untuk itu sekolah harus mengetahui dan menjalankan serta berupaya untuk meningkatkan peran serta masyarakat untuk bersama-sama menanggung pendidikan. Dengan kata lain, pemerintah berharap masyarakat dapat semakin berkontribusi dan memegang peranan yang lebih banyak dalam upaya meningkatkan mutu pendidikan sekolah di 
sekitarnya.

Untuk mewujudkan hal di atas, pemerintah terus berupaya menyerukan bahwa pendidikan adalah tanggung jawab bersama antara pemerintah, orang tua, dan masyarakat. Sidi dalam Mulyasa (2005:7) mengungkapkan bahwa kebijakan penyelenggaraan pendidikan nasional yang perlu direkonstruksi dalam rangka otonomi daerah salah satunya berkaitan dengan relevansi pendidikan yang mengarah pada pendidikan berbasis masyarakat. Peningkatan peran serta orang tua dan masyarakat pada level operasional melalui komite sekolah.

Sejalan dengan ini, Kementerian Agama mendirikan sekolah-sekolah bernuansa keagamaan untuk mendukung penciptaan manusia-manusia terdidik dan berakhlak mulia. Salah satu yang didirikan Kementerian Agama adalah Madrasah Aliyah Swasta yang tersebar di seluruh Indonesia. Pendirian Madrasah Aliyah Swasta diharapkan dapat membantu mampu menghasilkan manusia dan masyarakat bangsa Indonesia yang memiliki sikap agamis, berkemampuan ilmiah-amaliyah, terampil dan profesional, sehingga akan senantiasa sesuai dengan tatanan kehidupan (Depag, 2004:16). Tujuan yang demikian mulia ini, mempersyaratkan kepedulian semua pihak, baik dari keluarga, masyarakat, serta organisasi dan institusi pendidikan madrasah. Menyadari pentingnya peningkatan mutu kehidupan manusia, maka Kementerian Agama terus berupaya mewujudkan amanat tersebut melalui berbagai usaha pembangunan pendidikan yang lebih bermutu antara lain: (1) peningkatan keinginan masyarakat untuk memasuki dan belajar di madrasah-madrasah; (2) sosialisasi kegiatan-kegiatan belajar pada madrasah-madrasah; (3) pencitraan madrasah-madrasah sebagai lembaga pendidikan yang bermutu. Dengan upaya tersebut diharapkan akan bertambah keinginan calon siswa untuk memasuki madrasah-madrasah, dan madrasah menjadi pilihan pertama untuk melanjutkan pendidikannya.

Observasi awal yang peneliti lakukan pada Madrasah Aliyah Swasta di Kota Binjai, diperoleh informasi dari kepala sekolah bahwa terjadi penurunan jumlah calon siswa yang mendaftar ke madrasah. Informasi ini didukung data pengawas Kementerian Agama yang menyatakan banyak calon siswa yang memilih memasuki SMA-SMA swasta favorit guru dibandingkan Madrasah Aliyah Swasta. Umumnya calon siswa tidak memilih Madrasah Aliyah Swasta disebabkan banyak faktor, di antaranya: pelajaran yang diberikan terlalu banyak dengan adanya mata pelajaran agama, kesempatan untuk melanjutkan ke perguruan tinggi negeri (USU, Unimed) lebih kecil dibanding bila lulus dari SMA, dan sebagainya.

Sekolah sebagai lembaga pendidikan formal perlu meningkatkan respon positif masyarakat sekitarnya untuk keperluan pengembangannya. Respon positif terhadap pencitraan sekolah dapat terlihat dari perwujudan persepsi, realitas dan opini publik yang seiring berjalannya waktu membangun reputasi sekolah. Untuk membangun reputasi dan pencitraan tersebut, humas berperan dalam menangani reputasi dan mampu memberikan gagasan yang cemerlang demi peningkatan reputasi mendatang. Oliver (2007:4) menyebutkan humas adalah manajemen reputasi organisasi. Humas mengidentifikasikan persepsi yang dipegang oleh organisasi dan memberi informasi mengenai kinerja organisasi kepada semua audiens yang relevan. Humas menyangkut pengembangan reputasi yang pantas untuk sebuah organisasi, yang didasarkan pada kinerja. Reputasi ini tidak harus baik, tetapi hanya yang pantas diperoleh organisasi ini.

Kusumastuti (2002:17) mengungkapkan sasaran humas adalah publik, yakni 
sekelompok orang dalam masyarakat yang memiliki karakteristik kepentingan yang sama. Dalam praktik publik dikelompokkan menjadi dua, yakni: Publik internal yang meliputi: pemegang saham, pengelola dan karyawan. Dalam penelitian ini yang menjadi publik internal adalah Civitas Akademika yang terdiri dari tenaga edukatif yakni guru, tenaga administratif yakni karyawan dan para siswa.

Humas telah diformulasikan dengan cara yang berbeda-beda tergantung pada sekolah yang membuat formulasi itu. Formulasi pentingnya hubungan sekolah dengan masyarakat dalam hal ini ditangani bagian humas pada sekolah. Humas merupakan pengembangan dan pemeliharaan kerjasama yang efesien untuk menyampaikan saluran informasi dua arah. Bertujuan memberikan pemahaman antara pihak sekolah (pemimpin), komunitas sekolah (guru, TU, dan siswa) dan masyarakat (orang tua, masyarakat sekitar, dan lembaga lain di luar sekolah).

Program sekolah hanya dapat berjalan lancar apabila mendapat dukungan masyarakat. Oleh karena itu pemimpin sekolah perlu terus menerus membina hubungan yang baik antara sekolah dan masyarakat. Sekolah perlu banyak memberi informasi kepada masyarakat tentang program-program dan problem-problem yang dihadapi, agar masyarakat mengetahui dan memahami masalah-masalah yang dihadapi sekolah. Dari pemahaman dan pengertian ini dapat dihadapkan adanya umpan balik yang sangat berguna bagi pengembangan program sekolah lebih lanjut dan diharapkan pula tumbuhnya rasa simpati masyarakat terhadap program-program sekolah, yang dapat mengundang partisipasi yang aktif di masyarakat.

Sementara proses pendidikan merupakan berubahnya sesuatu menjadi sesuatu yang lain. Selanjutnya output pendidikan merupakan kinerja sekolah, yaitu prestasi sekolah yang dihasilkan dari proses dan perilaku sekolah. Tanpa adanya proses yang baik, sekolah yang bermutu juga mustahil untuk dicapai (Zahroh, 2014:28).

Konsep yang terdapat pada manajemen peningkatan mutu sekolah seharusnya lebih memfokuskan diri pada perbaikan proses pendidikan secara terus-menerus dan berkesinambungan. Menurut Zahror (2014:33) beberapa karakter dari konsep manajemen mutu sekolah adalah: (a) lingkungan sekolah yang aman dan tertib, (b) sekolah memiliki misi dan target mutu yang ingin dicapai, (c) sekolah memiliki kepemimpinan yang kuat, (d) adanya harapan yang tinggi dari personel sekolah untuk berprestasi, (e) adanya pengembangan staf sekolah yang terus-menerus sesuatu tuntutan IPTEK, (f) adanya pelaksanaan evaluasi yang terus-menerus terhadap berbagai aspek akademik dan administrasi, dan pemanfaatan hasilnya untuk penyempurnaan/ perbaikan mutu, dan (g) adanya komunikasi dan dukungan intensif dari orang tua siswa/ masyarakat.

Terkait dengan permasalahan di atas, dirasakan penting untuk melakukan suatu penelitian dalam bentuk mini riset yang melihat keterkaitan antara humas dengan mutu pendidikan. Untuk itu peneliti berkeinginan melakukan penelitian dengan judul Pengelolaan Hubungan Masyarakat dan Korelasinya dengan Mutu Pelayanan Pendidikan Madrasah $\begin{array}{llll}\text { Aliyah Swasta } & \text { di } & \text { Kota }\end{array}$ 


\section{B. Kajian Pustaka}

\section{Mutu Pelayanan Pendidikan}

Secara umum, mutu adalah gambaran dan karakteristik menyeluruh dari barang atau jasa yang menunjukkan kemampuannya dalam memuaskan kebutuhan yang diharapkan atau yang tersirat. Zahroh (2014:27) menyatakan mutu pendidikan identik dengan hasil keluaran (output) yang diproses secara maksimal oleh lembaga pendidikan.

Pandangan umum, mutu merupakan suatu konsep yang mutlak, seperti pada umumnya orang menilai restoran yang mahal atau mobil yang mewah. Dalam konteks manajemen mutu terpadu mutu bukan hanya merupakan suatu gagasan, melainkan suatu filosofi dan metodologi dalam membantu lembaga untuk mengelola perubahan secara totalitas dan sistemik, melalui perubahan nilai, visi, misi dan tujuan. Suderajat (2005:2) menuturkan bahwa mutu pendidikan dengan definisi yang relatif mempun yai dua aspek yaitu:

a. Pengukuran kemampuan lulusan sesuai dengan tujuan sekolah yang ditetapkan dalam kurikulum.

b. Pengukuran terhadap pemenuhan kebutuhan dan tuntutan pelanggan, yaitu orang tua siswa dan masyarakat.

Berbicara tentang mutu pendidikan, masalahnya sangat kompleks dan tidak sesederhana yang dibayangkan. Peningkatan mutu pendidikan tidak bisa lepas dari proses pendidikan sebagai sebuah sistem. Menurut Nurdin (2005:79) ada beberapa indikator yang menjadi tolok ukur:

a. Hasil akhir pendidikan, hasil akhir pendidikan merupakan tujuan akhir pendidikan. Dari hasil tersebut diharapkan para lulusannya dapat memenuhi tuntutan masyarakat bila ia bekerja atau melanjutkan studi ke lembaga pendidikan yang lebih tinggi.

b. Hasil langsung, pendidikan, berupa: (1) pengetahuan; (2) sikap; dan (3) keterampilan. Hasil inilah yang sering digunakan sebgai kriteria keberhasilan pendidikan.

c. Proses pendidikan, proses pendidikan merupakan interaksi antara raw input, instrumental input, dan lingkungan, untuk mencapai tujuan pendidikan. Pada proses ini, tidak berbicara mengenahi wujud gedung sekolah dan alat-alat pelajaran, akan tetapi bagaimana mempergunakan gedung dan fasilitas lainnya agar siswa dapat belajar dengan baik.

d. Instrumental input, terdiri dari tujuan pendidikan, kurikulum, fasilitas dan media pendidikan, sistem administrasi pendidikan, guru, sistem penyampaian, evaluasi, serta bimbingan dan penyuluhan. Instrumental input tersebut harus dapat berinteraksi dengan raw input (siswa) dalam proses pendidikan.

e. Raw input dan lingkungan, juga mempengaruhi kualitas mutu pendidikan.

Dalam konteks pendidikan, menurut Kementerian Pendidikan Nasional pengertian mutu mencakup input, proses, dan output pendidikan. Input pendidikan merupakan sesuatu yang harus tersedia karena dibutuhkan demi berlangsungnya suatu proses. Sementara proses pendidikan merupakan berubahnya sesuatu menjadi sesuatu yang lain. Selanjutnya output pendidikan merupakan kinerja sekolah, yaitu prestasi sekolah yang dihasilkan dari proses dan perilaku sekolah. Tanpa adanya proses yang baik, sekolah yang bermutu juga mustahil untuk dicapai

(Zahroh,

2014:28). 
Dengan demikian dapat disimpulkan bahwa pendidikan yang bermutu melalui proses, dengan tujuan membentuk lulusan yang sesuai dengan tujuan pendidikan yang bermutu memang harus menitikberatkan pada keterlibatan semua pihak dan suasana lingkungan sekolah yang kondusif untuk mewujudkan tujuan tersebut. Guru di sekolah tidak hanya sekedar sebagai penyampai berita tetapi sebagai fasilitator juga sebagai patner siswa dalam menemukan cara belajarnya, keterlibatan masyarakat sebagai laboratorium kehidupan yang mendukung dalam membentuk lulusan yang mampu memiliki kecerdasan sosial dan memiliki life skill yang baik.

\section{Pengelolaan Hubungan Masyarakat}

Setiap kegiatan dalam organisasi membutuhkan upaya menjalin hubungan dengan pihak-pihak yang terkait demi tercapainya tujuan organisasi tersebut baik hubungan dengan pihak intern maupun extern. Organisasi pendidikan adalah organisasi yang berdiri di tengahtengah masyarakat yang beragam dan berada diantara organisasi-organisasi lain yang bertujuan bermacam-macam pula.

Kegiatan Humas (Hubungan Masyarakat) adalah sebuah kegiatan untuk menyampaikan berita, dan kegiatan humas diharapkan berfungsi untuk menciptakan kesan positif. Sehingga dapat menciptakan ketertarikan untuk berkerjasama. Hubungan atau communication secara sederhana dapat diartikan sebagai proses penyampaian berita dari seseorang ke orang lain. Sedangkan mengenai Humas sampai sekarang masih banyak orang mempunyai penafsiran yang berbeda, kebanyakan dari mereka mendefinisikannya sesuai dengan cara mereka mempraktekkannya. Menurut kamus Fund dan Wagnel seperti dikutip Nasution (2006:12) pengertian humas adalah segenap kegiatan dan tehnik/ kiat yang digunakan organisasi atau individu untuk menciptakan atau memelihara suatu sikap dan tanggapan yang baik dari pihak luar terhadap keberadaan dan aktivitasnya.

Memang tidak dapat dipungkiri bahwa keterlibatan masyarakat mempunyai peran yang cukup besar bagi perkembangan organisasi di masa yang akan datang. Begitu juga dengan sekolah, suatu sekolah bisa dikatakan sukses jika mampu mendapatkan kepercayaan dari masyarakat. Karena bagaimanapun juga pendidikan adalah tanggungjawab bersama antara orang tua, sekolah dan masyarakat. Muhammad Supriono dan Sapari (2001:13) mengungkapkan bahwa peran serta masyarakat dalam bidang pendidikan memiliki posisi yang sangat penting dan strategis. Hal ini diakui secara resmi, baik dalam Undang-Undang maupun beberapa Peraturan Menteri bahwa pendidikan merupakan tanggung jawab bersama antara keluarga, masyarakat, dan pemerintah.

Mulyasa (2005:50) mengungkapkan hubungan sekolah dengan masyarakat pada hakikatnya merupakan suatu sarana yang sangat berperan dalam membina dan mengembangkan pertumbuhan pribadi siswa di sekolah. Dalam hal ini, sekolah sebagai sistem sosial merupakan bagian integral dan sistem sosial yang lebih besar, yaitu masyarakat. Sekolah dan masyarakat memiliki hubungan yang sangat erat dalam mencapai tujuan sekolah atau pendidikan secara efektif dan efisien. Sebaliknya sekolah juga harus menunjang pencapaian tujuan atau pemenuhan kebutuhan masyarakat, khususnya kebutuhan pendidikan.

Dari uraian tersebut di atas, bahwa pada hakikatnya keterlibatan masyarakat mempunyai peran yang cukup besar bagi kesuksesan suatu organisasi. Untuk itulah bagi setiap organisasi perlu meningkatkan kerja sama yang baik dengan masyarakatnya sehingga 
keberhasilan akan diraih sesuai dengan harapan. Bahwa hubungan antara lembaga pendidikan dan masyarakat sangatlah penting. Kesuksesan sebuah lembaga pendidikan dapat diukur seberapa besar kesuksesannya dalam menjalin hubungan dengan masyarakat, dalam arti sukses tidaknya sebuah lembaga pendidikan tergantung dari kemampuan sekolah terlibat dengan masyarakatnya.

Untuk itu diperlukan komunikasi yang nyambung atau komunikasi timbal balik antar masyarakat dengan lembaga pendidikan. Dalam hal inilah fungsi humas melalui perannya untuk menyampaikan informasi-informasi sebagaimana yang dikemukakan Nasution (2006:28) bahwa fungsi-fungsi manajemen humas dalam lembaga pendidikan meliputi:

a. Mampu sebagai mediator dalam menyampaikan komunikasi secara langsung (komunikasi tatap muka) dan tidak langsung (melalui media pers) kepada pimpinan lembaga dan publik intern (guru, karyawan, dan siswa).

b. Mendukung dan menunjang kegiatan-kegiatan yang berkaitan dengan mempublikasikan lembaga pendidikan. Dalam hal ini humas bertindak sebagai pengelola informasi kepada publik intern dan ekstern, seperti; menyampaikan informasi kepada pers, dan promosi, dan.

c. Menciptakan suatu citra yang positif terhadap lembaga pendidikannya.

Humas sebagai sebuah manajemen dalam lembaga pendidikan perannya tidak dapat dipisahkan dari sasaran atau objek dari masyarakat itu sendiri. Tingkat kesadaran tiap-tiap anggota masyarakat untuk berpartisipasi atau berperan sesuai dengan fungsi kemanusiaan dan fungsi sosialnya di dalam masyarakat, diperlukan sebuah gerakan penyadaran bersama. Karena jika kita berbicara masalah sosial, proses interaksi yang di dalamnya sebagai sebuah bentuk penyampaian informasi atau tersampaikannya informasi dari tiap pihak atau individu adalah sebuah kebutuhan. Sehingga untuk melaksanakan antar hubungan dan interaksi di dalam masyarakat tiap individu memerlukan kesadaran nilai-nilai dan kecakapan tertentu.

\section{Metode Penelitian}

\section{Jenis dan Sampel Penelitian}

Jenis Penelitian ini adalah penelitian kuantitatif jenis korelasional dengan menempatkan variabel penelitian ke dalam dua kelompok yaitu variabel bebas dan variabel terikat. Variabel bebas yaitu pengelolaan hubungan masyarakat, sedangkan variabel terikatnya adalah mutu pelayanan pendidikan. Sedangkan Populasi dalam Penelitian ini seluruh Guru-guru Madrasah Aliyah Swasta di Kota Binjai dengan jumlah 53 Guru dari 4 Madrasah Aliyah Swasta yang berbeda.

\section{Lokasi dan waktu Penelitian}

Penelitian ini rencananya dilakukan di Madrasah Aliyah Swasta di Kota Binjai, dan waktu penelitian dilaksanakan mulai bulan Juni 2017 s /d Mei 2018.

\section{Instrumen dan Prosedur Penelitian}

Instrumen yang digunakan dalam penelitian ini yaitu Angket Penyusan kuesioner Angket dilakukan dengan langkah-langkah sebagai berikut: (1) pembuatan kisi-kisi berdasarkan indikator dan deskriptor, (2) menyusun pernyataan atau item yang sesuai dengan 
kisi-kisi yang dibuat, dan (3) melakukan diskusi dan konsultasi dengan orang-orang yang ahli (pembimbing) agar diperoleh butir-butir yang memenuhi validitas isi (content validity). Penyusunan butir-butir pernyataan kuesioner mempertimbangkan kemudahan pengisian oleh responden, sehingga penyusunannya menperhatikan beberapa hal penting, antara lain: (1) menghindari pernyataan yang meragukan atau ambigu; (2) menghindari kata-kata yang terlalu abstrak; dan (3) tidak menggunakan kata-kata yang mencurigakan atau antipati. Berikut ini dapat dilihat rekapitulasi kedua instrumen penelitian sebelum dilakukan uji coba atau validitas angket.

Pendekatan yang digunakan dalam penelitian ini adalah pendekatan kuantitatif jenis korelasional dengan menempatkan variabel penelitian ke dalam dua kelompok yaitu variabel bebas dan variabel terikat. Variabel bebas yaitu pengelolaan hubungan masyarakat (X), sedangkan variabel terikatnya adalah mutu pelayanan pendidikan(Y). Menurut Arikunto (2005) penelitian korelasional dimaksudkan untuk mengetahui ada tidaknya hubungan antara dua variabel atau lebih. Penelitian dengan kajian korelasional akan dapat memprediksi hubungan antara variabel bebas dengan variabel terikat. Teknik analisis yang digunakan adalah korelasi dan regresi. Pendekatan analisisnya adalah analisis deskriptif kuantitatif yaitu menggambarkan apa adanya hubungan tentang suatu variabel melalui angka-angka.

\section{Pembahasan Hasil Penelitian}

\section{Deskrifsi hasil Penelitian}

Setelah penulis melakukan penelitian maka penulis mengumpulkan seluruh hasil angket yang telah dijawab oleh responden yang selanjutnya peneliti analisa.

Tabel 5

Ringkasan Deskripsi Data Variabel X dan Y

\begin{tabular}{|c|c|c|}
\hline Statistik Dasar & $\mathbf{X}$ & $\mathbf{Y}$ \\
\hline $\mathbf{N}$ & 53 & 53 \\
\hline Mean & 32,04 & 32,09 \\
\hline Median & 32,6 & 32,65 \\
\hline Modus & 33,9 & 33,41 \\
\hline Simp. Baku & 4,27 & 4,1 \\
\hline Minimum & 22 & 22 \\
\hline Maksimum & 39 & 38 \\
\hline
\end{tabular}

Penelitian ini terdiri dari dua variabel yaitu satu variabel bebas dan satu variabel terikat. Data variabel bebas yaitu variabel Pengelolaan Hubungan Masyarakat (X) dan data variabel terikat yaitu Mutu Pelayanan Pendidikan Madrasah Aliyah Swasta (Y). Dari pemeriksaan yang telah dilakukan terhadap data, ternyata seluruh data layak diolah serta dianalisis. Dengan kata lain, deskripsi data ini memuat informasi tentang skor tertinggi, skor terendah, mean, median dan lain-lain. Berikut ini ditampilkan perhitungan statistik dasar kedua 


\section{Distribusi Data Variabel Pengelolaan Hubungan Masyarakat (X)}

Berdasarkan data yang diperoleh diketahui bahwa skor terendah 22 dan skor tertinggi 39. Rata-rata skor (Mean) sebesar 32,04; Median sebesar 32,6; Modus sebesar 33,9; Dan simpangan baku sebesar 4,27.

Tabel 6

Distribusi Frekwensi Variabel Pengelolaan Hubungan

Masyarakat (X)

\begin{tabular}{|c|c|c|c|}
\hline Kelas & Interval & $\begin{array}{c}\text { Frekuensi } \\
\text { Mutlak }\end{array}$ & $\begin{array}{c}\text { Frekuensi Relatif } \\
(\%)\end{array}$ \\
\hline 1 & $20-22$ & 2 & $3,77 \%$ \\
\hline 2 & $23-25$ & 2 & $3,77 \%$ \\
\hline 3 & $26-28$ & 6 & $11,32 \%$ \\
\hline 4 & $29-31$ & 11 & $20,75 \%$ \\
\hline 5 & $32-34$ & 15 & $28,30 \%$ \\
\hline 6 & $35-37$ & 14 & $26,41 \%$ \\
\hline 7 & $38-40$ & 3 & $5,66 \%$ \\
\hline \multicolumn{2}{|r|}{ Jumlah } & 53 & $100 \%$ \\
\hline
\end{tabular}

Berdasarkan tabel ini, dapat diketahui bahwa data yang diperoleh dari 53 siswa sampel dapat diklasifikasi menjadi 7 kelas. 2 guru terdapat pada interval 20 - 22 atau 3,77\% , 2 guru terdapat pada interval $23-25$ atau 3,77 \%, 6 guru terdapat pada interval $26-28$ atau $11,32 \%, 11$ guru terdapat pada interval $29-31$ atau 20,75 \%, 15 guru terdapat pada interval $32-34$ atau 28,30\%, 14 guru terdapat pada interval $35-37$ atau 26,41\%, 3 guru terdapat pada interval $38-40$ atau $5,66 \%$.

Secara umum dapat disimpulkan bahwa 32 guru atau 60,37 \% skor variabel Pengelolaan Hubungan Masyarakat di atas nilai rata-rata dan 21 guru atau 39,63\% berada dibawah nilai rata-rata. disamping itu diketahui bahwa frekuensi tertinggi pada kelas interval 32-34 dan terendah pada imterval 20-22 dan 23-25.

\section{Distribusi Variabel Mutu Pelayanan Pendidikan Madrasah Aliyah Swsta (Y)}

Berdasarkan data yang diperoleh diketahui bahwa skor terendah 22 dan skor tertinggi 38. Rata-rata skor (Mean) sebesar 32,09; Median sebesar 32,65; Modus sebesar 33,41; Dan simpangan baku sebesar 4,1.

Tabel 7

Distribusi Frekwensi Variabel Mutu Pelayanan Pendidikan

Aliyah Swasta (Y)

\begin{tabular}{|c|c|c|c|}
\hline Kelas & Interval & $\begin{array}{c}\text { Frekuensi } \\
\text { Mutlak }\end{array}$ & $\begin{array}{c}\text { Frekuensi } \\
\text { Relatif (\%) }\end{array}$ \\
\hline 1 & $20-22$ & 1 & $1,89 \%$ \\
\hline 2 & $23-25$ & 3 & $5,66 \%$ \\
\hline
\end{tabular}




\begin{tabular}{|c|c|c|c|}
\hline 3 & $26-28$ & 6 & $11,32 \%$ \\
\hline 4 & $29-31$ & 10 & $18,87 \%$ \\
\hline 5 & $32-34$ & 17 & $32,07 \%$ \\
\hline 6 & $35-37$ & 13 & $24,53 \%$ \\
\hline 7 & $38-40$ & 3 & $5,66 \%$ \\
\hline \multicolumn{2}{|r|}{ Jumlah } & 53 & $100 \%$ \\
\hline
\end{tabular}

Berdasarkan tabel ini, dapat diketahui bahwa data yang diperoleh dari 53 guru sampel dapat diklasifikasi menjadi 7 kelas. 1 guru terdapat pada interval $20-22$ atau 1,89\% , 3 guru terdapat pada interval $23-25$ atau 5,66 \%, 6 guru terdapat pada interval $26-28$ atau $11,32 \%, 10$ guru terdapat pada interval $29-31$ atau 18,87\%, 17 guru terdapat pada interval $32-34$ atau 32,07 \%, 13 guru terdapat pada interval $35-37$ atau 24,53\%, 3 guru terdapat pada interval $38-40$ atau $5,66 \%$.

Secara umum dapat disimpulkan bahwa 33 guru atau 62,26 \% skor variabel Mutu Pelayanan Pendidikan Madrasah Aliyah Swasta diatas nilai rata-rata dan 20 guru atau 37,74\% berada dibawah nilai rata-rata.disamping itu diketahui bahwa frekuensi tertinggi pada kelas interval 32-34 dan terendah pada interval 20-22.

\section{Pengujian Persyaratan Analisis}

\section{a. Uji Normalitas $X$ dan $Y$}

Uji normalitas untuk masing-masing data penelitian dilakukan secara parametik dengan menggunakan penaksiran rata-rata dan simpangan baku. Untuk mengetahui apakah variabel $\mathrm{X}$ dan $\mathrm{Y}$ berdistribusi normal atau tidak dilakukan dengan uji Kolmogorov-Smirnov. Hasil perhitungan kemudian dicari nilai $a_{\max }$ yang kemudian dikonsultasikan dengan $\mathrm{D}_{\text {tabel }}$ dengan taraf signifikan $\alpha=0,05$, variabel $\mathrm{X}$ dan $\mathrm{Y}$ berdistribusi normal jika $\mathrm{a}_{\max }<\mathrm{D}_{\text {tabel }}$, sebaliknya jika harga tersebut tidak terpenuhi maka variabel $\mathrm{X}$ dan $\mathrm{Y}$ tidak berdistribusi normal.

Ringkasan hasil pengujian normalitas atas variabel X dan Y berdistribusi normal dapat dilihat dari tabel berikut :

Tabel 8

Ringkasan Hasil Analisis Uji Normalitas

\begin{tabular}{|c|c|c|c|c|c|}
\hline Variabel & $\mathbf{d k}$ & $\mathbf{a}_{\max }$ & Taraf & $\mathbf{D}_{\text {tabel }}$ & Keterangan \\
\hline $\mathbf{X}$ & 53 & 0,1 & 0,05 & 0,19 & Normal \\
\hline $\mathbf{Y}$ & 53 & 0,13 & 0,05 & 0,19 & Normal \\
\hline
\end{tabular}

Berdasarkan tabel diatas dapat dijelaskan bahwa variabel $\mathrm{X}$ diperoleh $\mathrm{a}_{\max }=0,1$ dan untuk dk $=53$ pada $\alpha=0,05, \mathrm{D}_{\mathrm{tab}}=0,19$, sehingga $\mathrm{a}_{\max }=0,1<\mathrm{D}_{\mathrm{tab}}=0,19$. Selanjutnya dapat juga dijelaskan bahwa variabel $\mathrm{Y}$ diperoleh $\mathrm{a}_{\max }=0,13$ dan untuk $\mathrm{dk}=53$ pada $\alpha=0,05, \mathrm{D}_{\text {tab }}$ $=0,19$, sehingga $a_{\max }=0,13<\mathrm{D}_{\mathrm{tab}}=0,19$. Dengan demikian dapat disimpulkan bahwa variabel X dan Y berdistribusi normal. Hasil perhitungan bisa dilihat di Lampiran 7. 


\section{b. Uji Homogenitas Data}

Uji homogenitas data dilakukan dengan masing-masing data penelitian dilakukan secara parametik dengan menggunakan penaksiran rata-rata dan simpangan baku. Untuk mengetahui apakah variabel $\mathrm{X}$ dan $\mathrm{Y}$ bersifat homogen atau tidak dilakukan dengan Uji Fisher. Hasil perhitungan dari $\mathrm{F}_{\text {hit }}$ dikonsultasikan dengan $\mathrm{F}_{\text {tabel }}$ dengan taraf signifikan $\alpha=$ 0,05 , variabel $\mathrm{X}$ dan $\mathrm{Y}$ homogen jika $F_{\text {hitung }}<\mathrm{F}_{\text {tabel }}$, sebaliknya jika $F_{\text {hitung }}>\mathrm{F}_{\text {tabel }}$ maka tidak homogen.

Untuk menentukan apakah antara variabel X dan Y homogen maka :

$$
\begin{aligned}
& F_{\text {hitung }}=\frac{\text { Varian Terbesar }}{\text { Varian Terkecil }}=\frac{S \text { terbesar }}{S \text { terkecil }} \\
& F_{\text {hitung }}=\frac{4,04}{3,98}=1,01
\end{aligned}
$$

Dengan $\mathrm{db}_{\text {pembilang }}$ untuk varian terbesar $=53-1=52$, dan $\mathrm{db}_{\text {penyebut }}$ untuk varian terkecil $=53-1=52$, dengan taraf signifikan 5\% maka diperoleh $\mathrm{F}_{\text {tabel }}=1,58$

Maka dapat disimpulkan $\mathrm{F}_{\text {hitung }}<\mathrm{F}_{\text {tabel }}, \mathrm{H}_{\mathrm{o}}$ diterima dan data bersifat homogen

\section{c. Pengujian Hipotesis}

Untuk melihat adanya hubungan antara Variabel $\mathrm{X}$ dengan Variabel $\mathrm{Y}$, maka dilakukan uji hubungan dengan menggunakan Product Moment. Dengan ketentuan jika $\mathrm{r}_{\text {hitung }}$ $>\mathrm{r}_{\text {tabel }}$ pada taraf $5 \%$, maka $\mathrm{H}_{\mathrm{o}}$ ditolak dan jika $\mathrm{r}_{\text {hitung }}<\mathrm{r}_{\text {tabel }}$ pada taraf $5 \%$, maka $\mathrm{H}_{\mathrm{o}}$ diterima dengan $\mathrm{H}_{\mathrm{a}}=$ adanya hubungan dan $\mathrm{H}_{\mathrm{o}}=$ tidak adanya hubungan. Hasil perhitungan didapat sebagai berikut :

$$
\begin{aligned}
& \sum X=1697 \quad \sum Y^{2}=55671 \\
& \sum X^{2}=55183 \quad \sum X Y=55386 \\
& \sum \mathrm{Y}=1705 \\
& r_{\mathrm{Xy}}=\frac{\mathrm{N} \sum \mathrm{XY}-\left(\sum \mathrm{X}\right)\left(\sum \mathrm{Y}\right)}{\sqrt{\left(\mathrm{N}\left(\sum^{2}\right)^{-}\left(\sum^{\mathrm{X})^{2}}\right)^{(\mathrm{N}}\left(\sum^{\mathrm{Y}^{2}}\right)^{\left.-\left(\sum \mathrm{Y}\right)^{2}\right)}\right.}} \\
& r_{x y}=\frac{\{(53)(55386)\}^{-\{(1697)(1705)\}}}{\left.\sqrt{{ }^{(53}\left({ }^{55183}\right)^{\left.-1697^{2}\right)(53}(556 / 1}\right)^{\left.-1705^{2}\right)}} \\
& r_{x y}=\frac{}{\sqrt{(2924699-2879809)(29505632907025)}} \\
& r_{\mathrm{xy}}=\sqrt{(44890) \text { (43538) }} \\
& r_{x y}=\frac{42073}{44208,83} \\
& r_{x y}=\overline{0,952}
\end{aligned}
$$

Dari perhitungan diatas, didapatkan $r_{x y}=0,952$, sedangkan $r_{\text {tabel }}=0,279$ pada taraf signifikan $5 \%$, sehingga $r_{x y}>r_{\text {tabel }}$ dengan demikian maka diputuskan bahwa " Adanya hubungan antara Pengelolaan Hubungan Masyarakat dengan Mutu Pelayanan Pendidikan Madrasah Aliyah Swasta di Kota Binjai”. 
Setelah diperoleh nilai hubungan Product Moment, langkah selanjutnya adalah pengujian hipotesis dengan cara memasukkan nilai koefisien korelasi product moment kedalam rumus uji $\mathrm{t}$ sebagai berikut :

$$
\begin{aligned}
& \mathrm{t}=\frac{\mathrm{r} \sqrt{\mathrm{n}-2}}{\sqrt{1-\mathrm{r}^{2}}} \\
& \mathrm{t}=\frac{0,952 \sqrt{53-2}}{\sqrt{1-0,952^{2}}} \\
& \mathrm{t}=\frac{0,952(7,14)}{\sqrt{1-0,906}} \\
& \mathrm{t}=\frac{6,8}{0,307} \\
& \mathrm{t}=\frac{6,8}{0,307} \\
& \mathrm{t}=22,15
\end{aligned}
$$

Dengan ketentuan jika $t_{\text {hitung }}>t_{\text {tabel }}$ maka $H_{o}$ ditolak dan jika $t_{\text {hitung }}<t_{\text {tabel }}$ maka $H_{o}$ diterima. Untuk taraf signifikan $5 \%$ dan $\mathrm{dk}=51(53-2)$ diperoleh $t_{\text {tabel }}=2,31$ karena $t_{\text {hitung }}$ $>t_{\text {tabel }}$ dengan demikian $\mathrm{H}_{\mathrm{a}}$ diterima dan dapat disimpulkan bahwa antara variabel $\mathrm{X}$ dengan variabel $\mathrm{Y}$ ada pengaruhnya, artinya "Ada Hubungan yang signifikan antara Pengelolaan Hubungan Masyarakat dengan Mutu Pelayanan Pendidikan Madrasah Aliyah Swasta di Kota Binjai”.

Untuk mengetahui berapa besar hubungan variabel $\mathrm{X}$ dan $\mathrm{Y}$ digunakan rumus korelasi determinasi sebagai berikut :

$$
\begin{aligned}
& D=r_{x y}^{2} \times 100 \% \\
& D=0,952^{2} \times 100 \% \\
& D=0,906 \times 100 \% \\
& D=90,6 \%
\end{aligned}
$$

Dengan mendistribusikan harga $\mathrm{r}_{\mathrm{xy}}{ }^{2}$ ke dalam $\mathrm{D}=\mathrm{r}_{\mathrm{xy}}{ }^{2} \mathrm{x} 100 \%$ diperoleh $\mathrm{D}=0,952^{2}$ $\mathrm{x} 100 \%=90,6 \%$. Adapun besarnya sumbangan variabel $\mathrm{X}$ dan $\mathrm{Y}$ secara bersamaan yakni variabel Pengelolaan Hubungan Masyarakat (X) dan Mutu Pelayanan Pendidikan Madrasah Aliyah Swasta di Kota Binjai (Y) adalah sebesar 90,6\%.

\section{E. Kesimpulan}

Dari Penelitian yang sudah dilakukan, sementara ini penelii hanya bisa menarik kesimpulan bahwa, (1) terdapat hubungan yang signifikan antara pengelolaan hubungan masyarakat dengan mutu pelayanan pendidikan Madrasah Aliya Swasta di kota Binjai, (2) secara bersama-sama terdapat hubungan yang positif antara pengelolaan hubungan masyarakat dengan Mutu Pelayanan Pendidikan Madrasah Aliyah Swasta di Kota Binjai, didapatkan $r_{x y}=0,952$ (tergolong tinggi), sedangkan $r_{\text {tabel }}=0,274$ pada taraf signifikan $5 \%$, sehingga $r_{x y}>r_{\text {tabel }}$ dengan demikian maka diputuskan bahwa Adanya Hubungan yang signifikan antara Pengelolaan Hubungan Masyarakat dengan Mutu Pelayanan Pendidikan Madrasah Aliyah Swasta di Kota Binjai. 


\section{F. Daftar Pustaka}

Arikunto, Suharsimi. 2005. Metode Penelitian Pendidikan: Suatu Pendekatan Proses. Jakarta: Rineka Cipta.

Hadjar, Ibnu. 1996. Metode Penelitian Sosial. Jakarta: Bina Aksara

Kusumastuti, Frida. 2002. Dasar-Dasar Hubungan Masyarakat. Jakarta Selatan: Ghalia Indonesia.

Mulyasa, E. 2005. Manajemen Berbasis Sekolah. Bandung: Remaja Rosdakarya.

Nasution, Zulkarnain. 2006. Manajemen Humas di Lembaga Pendidikan. Malang: UMM Press.

Nurdin, M. 2005. Pendidikan Yang Menyebalkan. Yogyakarta: Ar-Ruzz.

Oliver, Sandra. 2007. Strategi Public Relation. Jakarta: Esensi.

Ruslan, Rosady. 2008. Metode Penelitian Public Relations dan Komunikasi. Jakarta: Rajawali Pers.

Saroni, Muhammad. 2006. Manajemen Sekolah: Kiat Menjadi Pendidik Yang Kompeten. Jogjakarta: Ar-Ruzz.

Suderajat, Hari. 2005. Manajemen Peningkatan Mutu Berbasis Sekolah. Bandung: Cipta Cekas Grafika.

Sudjana, Nana. 1998. Menjadi Guru Profesional. Jakarta: Rineka Cipta.

Supriono, S. dan Ahmad Sapari. 2001. Manajemen berbasis Sekolah. Jawa Timur: SIC.

Zahror, Aminatul. 2014. Total Quality Management: Teori dan Praktik Manajemen Untuk Mendongkrak Mutu Pendidikan. Jakarta: Ar-Ruzz Media. 